\title{
Determination of the Protonation Constants of Some 3-Alkyl(Aryl)-4-(Substitutebenzylamino)-4,5-Dihydro-1H-1,2,4-Triazol-5- ones by the Potentiometric Method in Ethanol-Water Mixtures
}

\author{
F. İslamoğlu ${ }^{1^{*}}$, B. Kahveci ${ }^{1}$ and Y. İslamoğlu ${ }^{2}$ \\ ${ }^{1}$ Department of Chemistry, Faculty of Sciences and Arts, Rize University, Rize 53100, Turkey \\ ${ }^{2}$ Faculty of Medicine, Atatürk University, Erzurum 25240, Turkey \\ e-mail:fatihislamoglu53@hotmail.com.tr
}

\begin{abstract}
To gain more information about the effect of solvent on 4,5-dihydro-1H-1,2,4-triazol-5ones, the stoichiometric protonation constants of thirteen triazoles in ethanol-water mixtures were determined at an ionic strength of $0.10 \mathrm{M} \mathrm{NaCl}$ and at $25.0 \pm 0.1{ }^{\circ} \mathrm{C}$ under nitrogen atmosphere. A potentiometric method was used and the calculation was carried out using the PKAS computer program. The corresponding $p K_{a}$ values of these triazoles were determined in ethanol-water mixtures. Thus, the effects of solvent and molecular structure upon acidity were investigated. The logarithm of the protonation constants of the abovementioned 4,5-dihydro-1H-1,2,4-triazol-5-ones linearly decreased with increases in ethanol contents but the values that determined $80 \%$ ethanol did not follow this linear trend. The variation of these constants is discussed on the basis of specific solute-solvent interactions.
\end{abstract}

\section{INTRODUCTION}

Acidity measurements of organic compounds have a long history dating back to the end of the 19th century, when the first $\mathrm{pK}_{\mathrm{a}}$ was measured. Since then a vast body of data on acidities in various solvents has been collected [1-4]. The measurements have mostly been limited to polar solvents, however, with water being by far the most exploited medium, followed by alcohols and dipolar aprotic solvents.

Several studies, involving the formation and investigation of biological activities of some 4,5 - dihydro - $1 H$ - 1,2,4 - triazol-5-one derivatives, have been reported [5-16]. On the other hand, it is known that 4,5-dihydro- $1 \mathrm{H}$ 1,2,4-triazol-5-one rings have weak acidic properties.

The acidity of a compound in a given medium is influenced by both the electronic effects of the substituents and the solvent effects of the medium. Moreover, it is sometimes extremely difficult to assess how much each effect contributes to the acidity.
Small differences in acidity between similar molecules are also extremely difficult to interpret and one must be very careful in deciding which structural effect is the main influence on acidity.

A number of studies have been reported on the protonation constants of 4,5-dihydro- $1 \mathrm{H}$ 1,2,4-triazol-5-one derivatives in different media [17-20], however, very little information on the protonation constants of 4,5 - dihydro - $1 H$ - 1,2,4 - triazol - 5 - one derivatives in water and organic solvent-water mixtures has been published so far [21-23]. There have been no reports dealing with these triazoles investigated either in water or in organic solvent-water mixtures.

This paper, therefore, deals with the determination of the stoichiometric protonation constants of some 4,5-dihydro$1 H$-1,2,4-triazol-5-one derivatives. Moreover this work reports an investigation aimed at gaining information about the effect of solvent composition on the protonation constants of 4,5-dihydro- $1 H$-1,2,4-triazol-5one derivatives.

\footnotetext{
* Author for correspondence
} 


\section{EXPERIMENTAL}

In this study, 13 new 3-alkyl(aryl) - 4 (substitutebenzylamino) - 4,5 - dihydro - $1 \mathrm{H}$ 1,2,4 - triazol - 5 - ones ((1) 3 - ethyl - 4 -(pchlorobenzylamino) - 4,5 - dihydro $-1 H-1,2,4-$ triazol - 5 - one, (2) 3 - benzyl - 4 - (m chlorobenzylamino) $-4,5$ - dihydro - $1 H-1,2,4-$ triazol - 5 - one, (3) 3 - benzyl - 4 - (p chlorobenzylamino) - 4,5 - dihydro- $1 H-1,2,4-$ triazol - 5-one, (4) 3-p-chlorobenzyl-4-(pchlorobenzylamino)-4,5-dihydro- $1 H$ - 1,2,4 triazol - 5 - one, (5) 3 -p-methylbenzyl-4-(pchlorobenzylamino) - 4,5 - dihydro- $1 H-1,2,4-$ triazol - 5 - one, (6) 3 - methyl - 4-(pfluorobenzylamino) - 4,5 - dihydro- $1 H-1,2,4-$ triazol - 5 - one, (7) 3 - ethyl - 4 - (p fluorobenzylamino) - 4,5 - dihydro - $1 H$ 1,2,4 - triazol - 5 - one, (8) 3 - benzyl - 4 -(pfluorobenzylamino) - 4,5 - dihydro - $1 H$ $1,2,4$ - triazol - 5 - one, (9) 3 - p methylbenzyl - 4 -(p-fluorobenzylamino) - 4,5 - dihydro - $1 H$ - 1,2,4 - triazol - 5 - one, (10) 3 - p - chlorobenzyl -4-(p-fluorobenzylamino)4,5-dihydro-1H-1,2,4-triazol-5-one, (11) 3methyl-4-(m-bromobenzylamino)-4,5-dihydro -1H-1,2,4-triazol-5-one, (12) 3-ethyl-4-(mbromobenzylamino) - 4,5 - dihydro- $1 H-1,2,4-$ triazol - 5 - one, (13) 3 - phenyl - 4 - (m bromobenzylamino) - 4,5 - dihydro- $1 H-1,2,4-$ triazol-5-one) were synthesized and the purity of the substances was determined by potentiometric titration. The ethanol utilized was purified as described elsewhere [24]. Doubly distilled conductivity water was used as aqueous medium as well as for the preparation of ethanol-water mixtures. All other chemicals used in this investigation were reagent grade purity.

Hydrochloric acid solution $0.10 \mathrm{M}$ was prepared in water and standardized against sodium carbonate. Sodium hydroxide solutions $0.10 \mathrm{M}$ were prepared as $10 \%, 20 \%$, $30 \%, 40 \%, 50 \%, 60 \%, 70 \%$ and $80 \%(\mathrm{v} / \mathrm{v})$ aqueous ethanol solutions and stored in a glass bottle protected against the atmosphere. The base solutions were standardized via a linear least-squares fit of Gran plots for endpoint determination obtained from hydrochloric acid $[25,26]$.

All potentiometric measurements were performed in an $80 \mathrm{~mL}$ jacketed titration cell thermostated at $25.0 \pm 0.1{ }^{\circ} \mathrm{C}$ and under nitrogen atmosphere. An Orion 720A Model $\mathrm{pH}$-ionmeter, fitted with a combined $\mathrm{pH}$ electrode (Ingold) containing a filling solution of $0.10 \mathrm{M} \mathrm{NaCl}$, was used for measuring the cell e.m.f. values. The potentiometric cell was calibrated before each experiment so that the hydrogen ion concenration rather than the activity was measured [27,28]. For all the solvent mixtures examined, reproducible values of autoprotolysis constants, $K_{a p}$, were calculated from several series of $\left[\mathrm{H}^{+}\right]$and $\left[\mathrm{OH}^{-}\right]$measurements at $0.10 \mathrm{M} \mathrm{NaCl}[27,29]$.

The following solutions prepared in water and each of the solvent mixtures studied (total volume $50.0 \mathrm{~mL}$ ) were titrated potentiometrically with $\mathrm{CO}_{2}$-free standard 0.1 $\mathrm{M}$ sodium hydroxide dissolved in the corresponding solvents: (i) $2.5 \times 10^{-3} \mathrm{M} \mathrm{HCl}$ (for cell calibration); (ii) $2.0 \times 10^{-3} \mathrm{M} \mathrm{HCl}+$ $2.5 \times 10^{-3} \mathrm{M}$ triazol compound. During each titration the ionic strength was maintained at $0.1 \mathrm{M} \mathrm{NaCl}$ and a potential reading was taken after a suitable time (normally 2-3 min.) for equilibration.

The protonation constants of the 4,5 - dihydro - $1 H$ - 1,2,4 - triazol - 5 - ones were calculated by analyzing the titration data using the computer programme developed by Motekaitis and Martell [27,30].

\section{RESULTS AND DISCUSSION}

The stoichiometric protonation constants $(\beta)$ for 4,5-dihydro-1H-1,2,4-triazol-5-ones determined in ethanol - water mixtures $25.0 \pm$ $0.1^{\circ} \mathrm{C}$ are given in Tables 1, 2 and 3, respectively. All the values presented are the average of at least 5 measurements and which standard deviations. These values are the equilibrium constants of the $\mathrm{A}^{-}+\mathrm{H}^{+} \leftrightarrow \mathrm{AH}$, where AH show 4,5-dihydro-1H-1,2,4-triazol5-ones and their protonated species respectively. The protonation constants given in Tables 1, 2 and 3 are considered in more detail in order to gain more information about the effect of solvent composition and specific effects of substituents on the acidity of the 4,5-dihydro- $1 \mathrm{H}$-1,2,4-triazol-5-ones in solvent mixtures. 


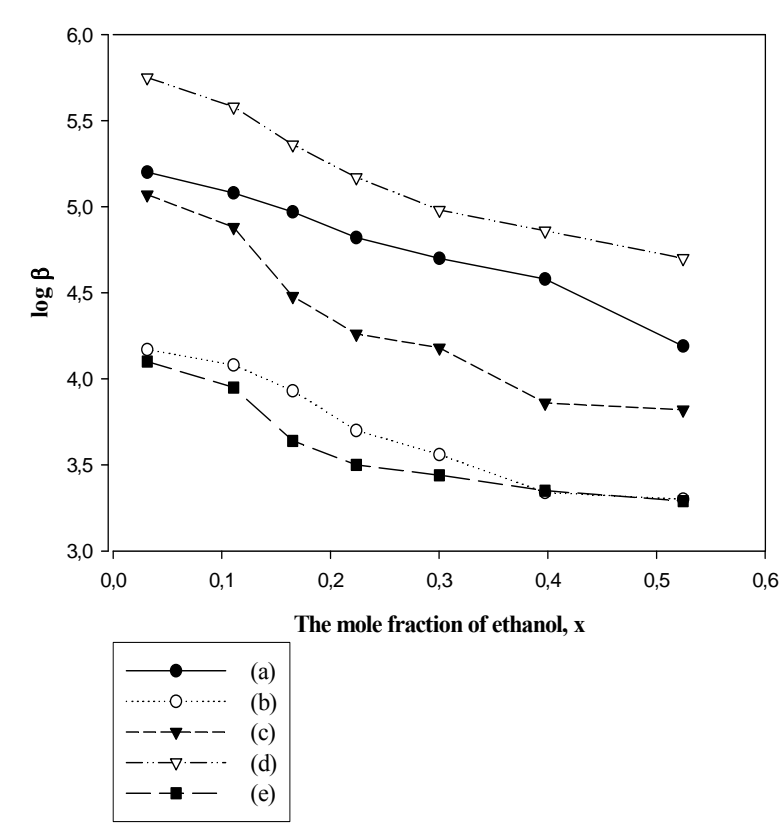

Figure 1. Variation in the protonation constants of some 4-(chlorobenzylamino)-4,5-dihydro- $1 H$ 1,2,4-triazol-5-ones against the mole fraction of ethanol: (a) 3-ethyl-4-(p-chlorobenzylamino) 4,5 - dihydro - $1 H$-1,2,4 - triazol - 5 - one; (b) 3benzyl-4-(m-chlorobenzylamino)- 4,5 - dihydro $1 H$ - 1,2,4 - triazol - 5 - one; (c) 3-benzyl-4-(pchlorobenzylamino) - 4,5 - dihydro - $1 H$ - 1,2,4 triazol - 5 - one; (d) 3 - p - chlorobenzyl - 4 - (p chlorobenzylamino) - 4,5 - dihydro - $1 H-1,2,4$ triazol - 5 - one; (e) 3 - p - methylbenzyl - 4 - (p chlorobenzylamino) - 4,5 - dihydro - $1 H-1,2,4$ triazol-5-one.

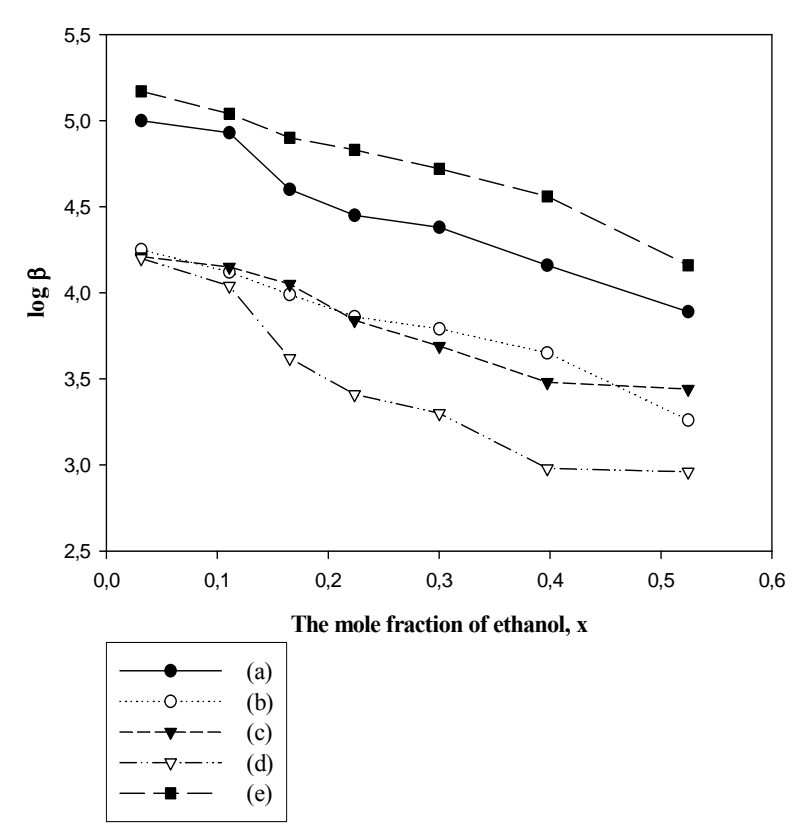

Figure 2. Variation in the protonation constants of some 4-(fluorobenzylamino)-4,5 dihydro-1 $H$-1,2,4-triazol-5-ones against the mole fraction of ethanol: (a) 3-methyl-4-(pfluorobenzylamino) - 4,5 - dihydro - $1 H-1,2,4$ - triazol - 5 - one; (b) 3 - ethyl - 4 - (p fluorobenzylamino) - 4,5 - dihydro - $1 H-1,2,4$ - triazol - 5 - one; (c) 3 - benzyl - 4 - (p fluorobenzylamino) - 4,5 - dihydro - $1 H-1,2,4-$ triazol - 5 - one; (d) 3 - p - methylbenzyl - 4(p-fluorobenzylamino) - 4,5-dihydro- $1 H-1,2,4-$ triazol - 5 - one; (e) 3 - p - chlorobenzyl - 4 (p-fluorobenzylamino) - 4,5-dihydro-1H-1,2,4triazol-5-one.

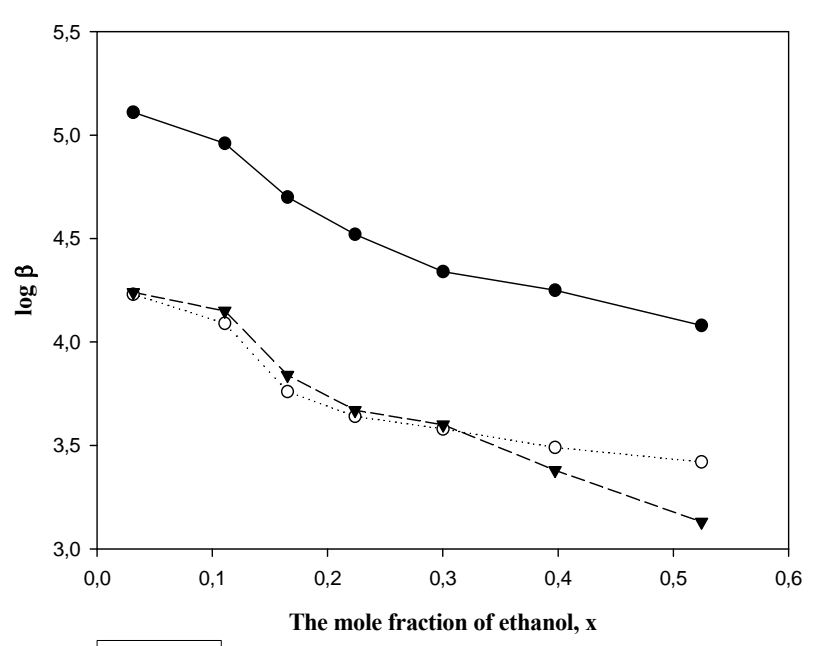

Figure 3. Variation in the protonation constants of some 4-(bromobenzylamino)-4,5 dihydro - $1 H-1,2,4$-triazol-5-ones against the mole fraction of ethanol: (a) 3-methyl-4-(mbromobenzylamino) - 4,5 - dihydro - $1 H$ 1,2,4 - triazol - 5 - one; (b) 3-ethyl-4-(mbromobenzylamino) - 4,5 - dihydro - $1 H$ 1,2,4 - triazol - 5 - one; (c) 3-phenyl-4-(mbromobenzylamino) - 4,5 - dihydro - $1 H-1,2,4-$ triazol-5-one. 


\begin{tabular}{|c|c|c|c|c|c|c|c|}
\hline $\begin{array}{l}\text { Some 3-alkyl(aryl)-4-(chlorobenzylamino) } \\
\text {-4,5-dihydro-1H-1,2,4-triazol-5-ones }\end{array}$ & $\begin{array}{c}\% 20 \mathrm{E}- \\
\% 80 \mathrm{~W} \\
\mathbf{x}=0.0314 \\
\log \beta\end{array}$ & $\begin{array}{c}\% 30 \mathrm{E}- \\
\% 70 \mathrm{~W} \\
x=0.1109 \\
\log \beta\end{array}$ & $\begin{array}{c}\% 40 \mathrm{E}- \\
\% 60 \mathrm{~W} \\
x=0.1653 \\
\log \beta\end{array}$ & $\begin{array}{c}\% 50 \mathrm{E}- \\
\% 50 \mathrm{~W} \\
x=2238 \\
\quad \log \beta\end{array}$ & $\begin{array}{c}\% 60 \mathrm{E}- \\
\% 40 \mathrm{~W} \\
x=0.3003 \\
\log \beta\end{array}$ & $\begin{array}{c}\% 70 \mathrm{E}- \\
\% 30 \mathrm{~W} \\
x=0.3974 \\
\log \beta\end{array}$ & $\begin{array}{c}\% 80 \mathrm{E}- \\
\% 20 \mathrm{~W} \\
x=5245 \\
\log \beta\end{array}$ \\
\hline $\begin{array}{l}\text { 3-ethyl-4-(p-chlorobenzylamino)-4,5- } \\
\text { dihydro-1H-1,2,4-triazol-5-one }\end{array}$ & $5.20 \pm 0.03$ & $5.08 \pm 0.05$ & $4.97 \pm 0.03$ & $4.82 \pm 0.02$ & $4.70 \pm 0.01$ & $4.58 \pm 0.02$ & $4.19 \pm 0.02$ \\
\hline $\begin{array}{l}\text { 3-benzyl-4-(m-chlorobenzylamino)-4,5- } \\
\text { dihydro- } 1 H-1,2,4 \text {-triazol-5-one }\end{array}$ & $4.17 \pm 0.02$ & $4.08 \pm 0.03$ & $3.93 \pm 0.05$ & $3.70 \pm 0.04$ & $3.56 \pm 0.03$ & $3.34 \pm 0.04$ & $3.30 \pm 0.02$ \\
\hline $\begin{array}{l}\text { 3-benzyl-4-(p-chlorobenzylamino)-4,5- } \\
\text { dihydro-1 } H \text {-1,2,4-triazol-5-one }\end{array}$ & $5.07 \pm 0.04$ & $4.88 \pm 0.04$ & $4.68 \pm 0.02$ & $4.26 \pm 0.06$ & $4.18 \pm 0.05$ & $3.86 \pm 0.03$ & $3.82 \pm 0.05$ \\
\hline $\begin{array}{l}\text { 3-p-chlorobenzyl-4-(p-chlorobenzylamino) } \\
\text {-4,5-dihydro- } 1 H-1,2,4 \text {-triazol-5-one }\end{array}$ & $5.75 \pm 0.02$ & $5.58 \pm 0.02$ & $5.36 \pm 0.06$ & $5.17 \pm 0.03$ & $4.98 \pm 0.02$ & $4.86 \pm 0.05$ & $4.70 \pm 0.04$ \\
\hline $\begin{array}{l}\text { 3-p-methylbenzyl-4-(p-chlorobenzylamino) } \\
\text {-4,5-dihydro-1H-1,2,4-triazol-5-one }\end{array}$ & $4.10 \pm 0.02$ & $3.95 \pm 0.01$ & $3.63 \pm 0.04$ & $3.50 \pm 0.04$ & $3.44 \pm 0.02$ & $3.35 \pm 0.03$ & $3.29 \pm 0.05$ \\
\hline
\end{tabular}

Table 1. Stoichiometric protonation constants of some 4-(chlorobenzylamino)-4,5-dihydro-1H-1,2,4-triazol-5-ones at $25.0 \pm 0.1{ }^{\circ} \mathrm{C}$ for different ethanol-water mixtures $(\mu=0.1 \mathrm{M} \mathrm{NaCl}, \mathrm{E}$ : ethanol, $\mathrm{W}:$ water, $\mathrm{x}=$ the mole fraction of ethanol).

\begin{tabular}{|c|c|c|c|c|c|c|c|}
\hline $\begin{array}{l}\text { Some 3-alkyl(aryl)-4-(fluorobenzylamino) } \\
\text {-4,5-dihydro-1H-1,2,4-triazol-5-ones }\end{array}$ & $\begin{array}{c}\% 20 \mathrm{E}- \\
\% 80 \mathrm{~W} \\
\mathbf{x}=0.0314 \\
\log \beta\end{array}$ & $\begin{array}{c}\% 30 \mathrm{E}- \\
\% 70 \mathrm{~W} \\
x=0.1109 \\
\log \beta\end{array}$ & $\begin{array}{c}\% 40 \mathrm{E}- \\
\% 60 \mathrm{~W} \\
x=0.1653 \\
\log \beta\end{array}$ & $\begin{array}{c}\% 50 \mathrm{E}- \\
\% 50 \mathrm{~W} \\
x=2238 \\
\log \beta\end{array}$ & $\begin{array}{c}\% 60 \mathrm{E}- \\
\% 40 \mathrm{~W} \\
\mathrm{x}=0.3003 \\
\log \beta\end{array}$ & $\begin{array}{c}\% 70 \mathrm{E}- \\
\% 30 \mathrm{~W} \\
\mathbf{x}=0.3974 \\
\log \beta\end{array}$ & $\begin{array}{c}\% 80 \mathrm{E}- \\
\% 20 \mathrm{~W} \\
x=5245 \\
\log \beta\end{array}$ \\
\hline $\begin{array}{l}\text { 3-methyl-4-(p-fluorob } \\
\text { dihydro- } 1 H-1,2,4 \text {-triaz }\end{array}$ & $0 \pm 0.04$ & .03 & 0.02 & 0.04 & 01 & .03 & 0.02 \\
\hline $\begin{array}{l}\text { 3-ethyl-4-(p-fluorobenzylamino)-4,5- } \\
\text { dihydro-1H-1,2,4-triazol-5-one }\end{array}$ & $4.25 \pm 0.03$ & $4.12 \pm 0.02$ & $3.99 \pm 0.02$ & $3.86 \pm 0.02$ & $3.79 \pm 0.03$ & $3.65 \pm 0.05$ & $3.26 \pm 0.02$ \\
\hline $\begin{array}{l}\text { 3-benzyl-4-(p-fluorobenzyl } \\
\text { dihydro-1H-1,2,4-triazol-5. }\end{array}$ & $1 \pm 0.06$ & $15 \pm 0.04$ & $4.05 \pm 0.06$ & $3.84 \pm 0.04$ & $3.69 \pm 0.06$ & $3.48 \pm 0.04$ & $3.44 \pm 0.04$ \\
\hline $\begin{array}{l}\text { 3-p-methylbenzyl-4-(p-fluo } \\
\text {-4,5-dihydro- } 1 H \text {-1,2,4-triaz }\end{array}$ & $.20 \pm 0.05$ & $4.04 \pm 0.04$ & $3.62 \pm 0.03$ & $3.41 \pm 0.06$ & $3.30 \pm 0.04$ & $2.98 \pm 0.02$ & $2.96 \pm 0.05$ \\
\hline $\begin{array}{l}\text { 3-p-chlorobenzyl-4-(p-fluorobenzylamino) } \\
\text {-4,5-dihydro-1H-1,2,4-triazol-5-one }\end{array}$ & $5.17 \pm 0.02$ & $5.04 \pm 0.05$ & $4.90 \pm 0.05$ & $4.83 \pm 0.05$ & $4.72 \pm 0.02$ & $4.56 \pm 0.04$ & $4.16 \pm 0.03$ \\
\hline
\end{tabular}

Table 2. Stoichiometric protonation constants of some 4-(fluorobenzylamino)-4,5-dihydro- $1 H$-1,2,4-triazol-5-ones at $25.0 \pm 0.1{ }^{\circ} \mathrm{C}$ for different ethanol-water mixtures ( $\mu=0.1 \mathrm{M} \mathrm{NaCl}, \mathrm{E}$ : ethanol, $\mathrm{W}$ : water, $\mathrm{x}=$ the mole fraction of ethanol). 


\begin{tabular}{|c|c|c|c|c|c|c|c|}
\hline $\begin{array}{l}\text { Some 3-alkyl(aryl)-4-(bromobenzylamino) } \\
\text {-4,5-dihydro-1H-1,2,4-triazol-5-ones }\end{array}$ & $\begin{array}{c}\% 20 \mathrm{E}- \\
\% 80 \mathrm{~W} \\
\mathbf{x}=0.0314 \\
\log \beta\end{array}$ & $\begin{array}{c}\% \% 30 \mathrm{E}- \\
\% 70 \mathrm{~W} \\
\mathbf{x}=0.1109 \\
\log \beta\end{array}$ & $\begin{array}{c}\% 440 \mathrm{E}- \\
\% 60 \mathrm{~W} \\
x=0.1653 \\
\log \beta\end{array}$ & $\begin{array}{c}\% 50 \mathrm{E}- \\
\% 50 \mathrm{~W} \\
x=2238 \\
\log \beta\end{array}$ & $\begin{array}{c}\% \% 60 \mathrm{E}- \\
\% 40 \mathrm{~W} \\
x=0.3003 \\
\log \beta\end{array}$ & $\begin{array}{c}\% 70 \mathrm{E}- \\
\% 30 \mathrm{~W} \\
x=0.3974 \\
\log \beta\end{array}$ & $\begin{array}{c}\% 80 \mathrm{E}- \\
\% 20 \mathrm{~W} \\
x=5245 \\
\log \beta\end{array}$ \\
\hline $\begin{array}{l}\text { 3-methyl-4-(m-bromobenzylamino)-4,5- } \\
\text { dihydro-1H-1,2,4-triazol-5-one }\end{array}$ & $5.11 \pm 0.03$ & $4.96 \pm 0.03$ & $4.70 \pm 0.02$ & $4.52 \pm 0.02$ & $4.34 \pm 0.04$ & $4.25 \pm 0.04$ & $4.08 \pm 0.03$ \\
\hline $\begin{array}{l}\text { 3-ethyl-4-(m-bromobenzylamino)-4,5- } \\
\text { dihydro- } 1 H \text {-1,2,4-triazol-5-one }\end{array}$ & $4.23 \pm 0.02$ & $4.09 \pm 0.03$ & $3.76 \pm 0.04$ & $3.64 \pm 0.02$ & $3.58 \pm 0.05$ & $3.49 \pm 0.02$ & $3.42 \pm 0.02$ \\
\hline $\begin{array}{l}\text { 3-phenyl-4-(m-bromobenzylamino)-4,5- } \\
\text { dihydro- } 1 H-1,2,4 \text {-triazol-5-one }\end{array}$ & $4.24 \pm 0.04$ & $4.15 \pm 0.05$ & $3.84 \pm 0.03$ & $3.67 \pm 0.03$ & $3.60 \pm 0.03$ & $3.38 \pm 0.02$ & $3.13 \pm 0.03$ \\
\hline
\end{tabular}

Table 3. Stoichiometric protonation constants of some 4-(bromobenzylamino)-4,5-dihydro- $1 H$-1,2,4-triazol-5-ones at $25.0 \pm 0.1{ }^{\circ} \mathrm{C}$ for different ethanol-water mixtures $(\mu=0.1 \mathrm{M} \mathrm{NaCl}, \mathrm{E}$ : ethanol, $\mathrm{W}$ : water, $\mathrm{x}=$ the mole fraction of ethanol).

\begin{tabular}{|c|c|}
\hline $\begin{array}{c}\text { Some 3-alkyl(aryl)-4-(chlorobenzylamino)- } \\
\text { 4,5-dihydro-1H-1,2,4-triazol-5-ones }\end{array}$ & $\begin{array}{c}\text { Equation } \\
\text { Coefficients, } \mathbf{r}\end{array}$ \\
\hline 3-ethyl-4-(p-chlorobenzylamino)-4,5-dihydro-1H-1,2,4-triazol-5-one & $\log \beta=-1.463(\mathrm{x})+5.147$ \\
\hline 3-benzyl-4-(m-chlorobenzylamino)-4,5-dihydro-1H-1,2,4-triazol-5-one & $\log \beta=-2.187(\mathrm{x})+4.104$ \\
\hline 3-benzyl-4-(p-chlorobenzylamino)-4,5-dihydro-1H-1,2,4-triazol-5-one & $\log \beta=-2.562(\mathrm{x})+4.982$ \\
\hline 3-p-chlorobenzyl-4-(p-chlorobenzylamino)-4,5-dihydro-1H-1,2,4-triazol-5-one & $\log \beta=-2.415(\mathrm{x})+5.684$ \\
\hline 3-p-methylbenzyl-4-(p-chlorobenzylamino)-4,5-dihydro-1H-1,2,4-triazol-5-one & $\log \beta=-2.318(\mathrm{x})+4.034$ \\
\hline
\end{tabular}

Table 4. Linear relationship between the protonation constants of some 4-(chlorobenzylamino)-4,5-dihydro-1H-1,2,4-triazol-5-ones and the mole fraction of ethanol (x) (from 0.0314 to 0.3974 ). 


\begin{tabular}{|c|c|c|}
\hline $\begin{array}{c}\text { Some 3-alkyl(aryl)-4-(fluorobenzylamino) } \\
\mathbf{- 4 , 5 - d i h y d r o - 1 H - 1 , 2 , 4 - t r i a z o l - 5 - o n e s}\end{array}$ & $\begin{array}{c}\text { Equation } \\
\text { Coefficients, } \mathbf{r}\end{array}$ \\
\hline 3-methyl-4-(p-fluorobenzylamino)-4,5-dihydro-1H-1,2,4-triazol-5-one & $\log \beta=-1.966(\mathrm{x})+4.926$ & -0.988 \\
\hline 3-ethyl-4-(p-fluorobenzylamino)-4,5-dihydro-1H-1,2,4-triazol-5-one & $\log \beta=-2.617(\mathrm{x})+4.182$ & -0.982 \\
\hline 3-benzyl-4-(p-fluorobenzylamino)-4,5-dihydro-1H-1,2,4-triazol-5-one & $\log \beta=-1.621(\mathrm{x})+4.164$ & -0.991 \\
\hline 3-p-methylbenzyl-4-(p-fluorobenzyl amino)-4,5-dihydro-1H-1,2,4-triazol-5-one & $\log \beta=-1.845(\mathrm{x})+4.147$ & -0.996 \\
\hline 3-p-chlorobenzyl-4-(p-fluorobenzylamino)-4,5-dihydro-1H-1,2,4-triazol-5-one & $\log \beta=-2.172(\mathrm{x})+5.149$ & -0.995 \\
\hline
\end{tabular}

Table 5. Linear relationship between the protonation constants of some 4-(fluorobenzylamino)-4,5-dihydro- $1 H$-1,2,4-triazol-5-ones and the mole fraction of ethanol (x) (from 0.0314 to 0.3974 ).

\begin{tabular}{|c|c|c|}
\hline $\begin{array}{c}\text { Some 3-alkyl(aryl)-4-(bromobenzylamino) } \\
-4,5-d i h y d r o-1 H-1,2,4-t r i a z o l-5-o n e s\end{array}$ & Equation & $\begin{array}{c}\text { Correlation } \\
\text { Coefficients, } \mathbf{r}\end{array}$ \\
\hline 3-methyl-4-(m-bromobenzylamino)-4,5-dihydro-1H-1,2,4-triazol-5-one & $\log \beta=-2.163(\mathrm{x})+5.028$ & -0.987 \\
\hline 3-ethyl-4-(m-bromobenzylamino)-4,5-dihydro-1H-1,2,4-triazol-5-one & $\log \beta=-1.853(\mathrm{x})+4.185$ & -0.994 \\
\hline 3-phenyl-4-(m-bromobenzylamino)-4,5-dihydro-1H-1,2,4-triazol-5-one & $\log \beta=-1.586(\mathrm{x})+4.196$ & -0.997 \\
\hline
\end{tabular}

Table 6. Linear relationship between the protonation constants of some 4-(bromobenzylamino)-4,5-dihydro-1H-1,2,4-triazol-5-ones and the mole fraction of ethanol (x) (from 0.0314 to 0.3974$)$. 
The numerical $\log \beta$ values for 4,5dihydro-1 $H$-1,2,4-triazol-5-ones

determined in ethan-ol - water mixtures decrease with increasing ethanol content in the solvent mixture, an example of which is given in the Figures 1, 2 and 3. They are observed that a nearly linear relationship exists between the aforemen- tioned protonation constants and the mole fraction of ethanol from 0.0314 to 0.3974 for all 4,5 -dihydro- $1 H$ 1,2,4-triazol-5-ones inves- tigated. However, $\log \beta$ values at a mole fraction of ethanol of 0.3974 are slightly higher than those expected from the linear trend. The linear equations and the related correlation coefficients for all 4,5-dihydro- $1 H$-1,2,4-triazol-5-ones are given Tables 4, 5 and 6 .

Many studies have shown that the equilibrium constant is linearly related to the fraction of organic solvent [31-35]. Our results obtained for 4,5-dihydro- $1 \mathrm{H}$ 1,2,4-triazol-5-ones are in good agreement with these. The dissociation constants of charged acids in ethanolwater mixtures vary with solvent composition in a manner that is not completely understood. Bates and coworkers [36,37] and Chattopadhyay and Lahiri [38] have examined the effect of a change in solvent composition on the dissociation of $\mathrm{BH}^{+}$and the related Gibbs energies of transfer in mixed solvents.

In this paper it is suggested that electrostatic charging effects resulting from the change in dielectric constant with solvent effects and the solutesolvent interactions have greater significance in the interpretation of solvent effects. Thus, we can explain our results obtained for 4,5-dihydro- $1 \mathrm{H}$ 1,2,4-triazol-5-ones by specific solvation effects. The derivations of linearity in $80 \%$ ethanol many results from the preferential solvation of solute by one of the components of the solvent mixture that could change the effective dielectric constant value in the cibotactic region [39].

Furthermore, another factor why an increase in the $\log \beta$ values of all 4,5-
dihydro-1H-1,2,4-triazol-5-ones are produced in ethanol-rich regions can be satisfactorily explained by differences in the solvent stabilization of the ionic species $\left(\mathrm{H}^{+}\right.$and $\left.\mathrm{AH}\right)$, brought about by changing the percentage of ethanol $[37,40]$.

Using the protonation constants obtained in this work, the effects of the type substitute groups on the acidity of the 4,5-dihydro-1 $H$-1,2,4-triazol-5-ones

studied have been discussed. The most important factor that effects the acidity and therefore the protonation constant of a compound is the structural effect.

Table 1 show that the 3-p-chlorobenzyl4-(p-chlorobenzylamino)-4,5-dihydro1H-1,2,4-triazol-5-one, Table 2 show that the 3-p-chlorobenzyl - 4 - (pfluorobenzylamino)-4,5-dihydro- $1 H$ -

1,2,4-triazol-5-one and Table 3 show that the 3-methyl - 4 - (m bromobenzylamino) - 4,5 -dihydro $-1 H$ 1,2,4-triazol-5-one has protonation constant higher than other 4,5-dihydro$1 \mathrm{H}$-1,2,4-triazol-5-ones in ethanol-water. This effect can be explained by taking the electronic effect of the substitute groups investigated into account.

\section{CONCLUSION}

The acidity of a 4,5-dihydro- $1 H$-1,2,4triazol-5-one is a result of various factors such as (i) the solvent effect; solvation power the tendency of forming hydrogen bonds, selective solvation, dielectric constant and the composition of the solution in the first solvation layer in the case of mixed solvents and (ii) structural effect, electronic effect, steric effect and the formation of hydrogen bonding.

\section{REFERENCES}

1. Kortüm G., Vogel W. and Andrussow K., Dissociation Constants of Organic Acids in Aqueous Solution, Plenium, New York, (1961).

2. Palm V., Tables of Rate and Equilibrium Constants of Heterolytic 
Organic Reactions, Ed.; MoscowTartu, (1985).

3. Izutsu K., Acid-base Dissociation Constants in Dipolar Aprotic Solvents; IUPAC Chemical Data Series No: 35; Blackwell Scientific: Oxford, (1990).

4. Bordwell F. G., Acc. Chem. Res., 21, 456. (1988).

5. Takimoto H. H. , Denault G. C. and Hotta S., J. Heterocycl. Chem., 3, 119, (1966).

6. Milcent R. and Redeuilh C., J. Heterocycl. Chem., 16, 403, (1979).

7. Milcent R. And Vicart P., J. Med. Chem., 18, 215, (1983).

8. Katritzky A. R. and Laurenzo K. S., J. Org. Chem., 53, 3978, (1988).

9. İkizler A. A., İkizler A. and Yildırım N., Monatsh. Chem., 122, 557, (1991).

10. İkizler A. A. and Yüksek H., Collect. Czech. Commun., 59, 731, (1994).

11. İkizler A. A., Yıldırım N. and Yüksek H., Modelling. Measurement \& Control C, AMSE Press, 54, 21, (1996).

12. Dash B., Mahapatra P. K., Pand D. and Pattnaik J. M., J. Indian Chem., 61, 1061, (1984).

13. Dash B., Patra M. and Mahapatra P. K., J. Indian Chem. Soc., 60, 772, (1983).

14. Emilsson H., Selander H.and Guarder J., Eur. J. Med. Chem.Chim. Ther., 20, 333, (1985).

15. İkizler A. A., Uçar F., Yüksek H., Aytin A., Yaşa I. and Gezer T., Acta Polen. Pharm.-Drug Res., 54, 135, (1997).
16. İkizler A. A., İkizler A., Yüksek H. and M. Serdar, Modelling. Measurement \& Control C, AMSE Press, 1, 25, (1998).

17. Herbert S. H. and Birdsall C. M., J. Am. Chem. Soc., 65, 54, (1943).

18. Nowak B. and Pawlak Z., J. Chem. Soc. Faraday Trans. I, 78, 2693, (1982).

19. Wada G., Tamura E., Okina M. and Nakamura M., Bull. Chem. Soc. Jpn., 55, 3064, (1982).

20. Köseoğlu F., Kılıç E. and Doğan A., Anal. Biochem., 277, 243, (2000).

21. Hughes D. L., Bergan J. J. and Grabowski E. J. J., J. Org. Chem., 55, 2579, (1986).

22. Benesch E. R., J. Am. Chem. Soc., 77, 5877, (1955).

23. Edsall J. T. and Blanchard M. H., J. Am. Chem. Soc., 55, 2337, (1933).

24. Perrin D. D. and Armerega W. L. F., Purification of Laboratory Chemicals, $1^{\text {st }}$ edn, Pergamon, Oxford, (1966).

25. Gran G., Acta. Chem. Scand., 4, 559, (1950).

26. Gran G., Analyst, 77, 661, (1952).

27. Martell A. E. and Motekaitis R. J., The Determination and Use of Stability Constants, VCH, Weinheim, (1988).

28. Meloun M., Havel J. and Högfelt H., Computation of Solution Equilibria, Wiley, New York, (1988). 
29. Woolley E. M., Hurkot D. G. and Hepler L. G., J. Phys. Chem., 74, 3908, (1970).

30. Motekaitis R. J. and Martell A. E., Can. J. Chem., 60, 168, (1982).

31. Niazi M. S. K. and Mollin J., Bull. Chem. Soc. Jpn., 60, 2605, (1987).

32. Panichajakul C. C. and Woolley E. M., Anal. Chem., 47, 1880, (1975).

33. Irving H. and Rossotti H., Acta. Chem. Scand., 10, 72, (1986).

34. Irving $H$. and Rossotti H., Analyst, 80, 245, (1955).

35. Gentile P. S., Cefole M. and Celiano A. V., J. Phys. Chem., 67, 1447, (1963).
36. Paabo M., Bates R. G. and Robinson R. A., J. Phys. Chem., 70, 247, (1965).

37. Bates R. G., J. Electroanal. Chem., 29, 1, (1971).

38. Chattopadhyay A. K. and Lahiri S. C., Electrochim. Acta., 27, 269, (1982).

39. Isaacs N. S., Physical Org. Chem., Longman, New York, (1986).

40. Bates R. G., Determination of $\mathrm{pH}$, Theory and Practice, 2nd edn., Wiley, New York, (1973).

Received: $31 / 5 / 2006$

Accepted: 22/11/2006 
